\title{
CONSTRUCTION OF PROMOTIONAL MESSAGE OF A HIGHER SCHOOL IN THE CONTEXT OF CHANGES IN BEHAVIORS OF POTENTIAL STUDENTS
}

\section{IZABELA OSTROWSKA}

University of Szczecin, Faculty of Management and Economics of Services, POLAND

e-mail: izabela.ostrowska@wzieu.pl

RECEIVED

ACCEPTED

JEL

CLASSIFICATION

KEYWORDS

ABSTRACT
10 December 2018

28 December 2018

M30, M39

promotion, university, generation Z

The task of university communication with a potential student is to provide information that will enable assessment of the available selection options and making a decision about studying at a given faculty and at a given university. Effective activities in the field of university communication with potential students require proper planning, also in terms of communication channels used. The starting point when choosing effective tools and communication channels is to learn the needs and expectations of the candidates for the studies. The aim of the article is to define communication channels in which young people undertaking studies seek information about the possibilities of studying and convincing arguments in order to increase the effectiveness of promotional messages from universities. The article base on results of own research. The on-line survey (CAWI) was conducted in September 2018 on a sample of 409 respondents in one of the economic faculties in the West Pomeranian Voivodeship (random sample).

\section{Introduction}

The development of the information society causes a change in many processes taking place in the economy, but also changes in consumer habits related to communication. The most important features of the information society include: the growing importance of information in all aspects of life, the widespread use of information technology, developed information and communication means, or extensive teleinformation infrastructure (Grzywińska-Rapca, 
Lorek, Markowski, 2018, p. 24). The development of information and communication technologies radically changes the nature of the business and non-business environment, as well as non-profit organizations such as public higher education institutions. Progress in this area leads to significant changes and reappraisals in the economic, social and cultural dimension (Gamper, 2012, pp. 333-353). The process of information transmission uses various channels and media, which are carriers of advertising or other forms of promotion (Wiktor, 2013, p. 129). Rapid changes in the accessibility to technology facilitate the development of modern communication channels, changing the way of conducting communication with various interest groups in the organization's environment (Alwahaishi, Snášel, 2013, p. 61).

The effectiveness of communication is higher if the sender and recipient of the message use the same coding methods and use the same communication channels (Heath, 2013, p. 12). To improve the effectiveness of communication, the university should reach with its messages the future students. It is worth emphasizing that the purpose of marketing communication is not only the transmission of specific information to the market, but the shaping of needs and stimulation of demand (Wiktor, 2013, p. 22). The aim of public higher education promotional activities is therefore not only to inform about the pursued fields of study, but above all to convince a potential candidate that it is worth studying and choosing this higher education course. The aim of the article is to define communication channels in which young people undertaking studies seek information about the possibilities of studying and convincing them with arguments in order to increase the effectiveness of promotional messages from universities. The article is based on the analysis of available statistical data, literature on the subject and the results of own research.

\section{Demographical changes}

As A. Pabian rightly observes, every college operates in a given environment and depends on it. The most important component of the university's environment is its clients - students and business entities who commission employees to perform research. The university should strive for a large number of students and principals, thanks to which it will be able to fully use the scientific and research potential it has. The lack of effective communication with the market is harmful to universities (Pabian, 2002, p. 138). The university loses potential students and instead of developing and investing, it has to sell out assets and close down the faculties which have not enough candidates. Since 2006, the number of students in Poland has been systematically decreasing. In the academic year 2016/2017, 1348.8 thousand were educated in 390 higher education institutions of all types. In comparison, in 2005/2006, when the number of students reached the maximum, i.e. 1,953.8, that is over 605 thousand more people. In the period of 11 years, the number of students has decreased by $31 \%$. The percentage of people deciding to take up higher education after lower secondary school is lower, and the number of people aged 18-24, i.e. the most important segment for the university, decreases (decrease by $31.0 \%$ compared to 2005) (GUS, 2017, pp. 25-26). In recent years, universities have begun to feel the effects of the demographic drop, which decreased the number of students in Poland (Figure 1). Forecasts show that the peak of this drop will take place in 2023.

Currently, there are about 130 state-owned universities in Poland and most of them suffer from the effects of the demographic decline. Many, also renowned universities, conduct additional recruitment also for full-time studies (Do 2023..., 2013). Public universities compete for full-time students with non-public institutions, but due to the decreasing number of people undertaking studies, competition between public universities is intensifying. In 2016/2017, there were 390 higher education institutions in Poland (including schools of the Ministry of National 
Defense and internal affairs and administration). Out of these, 132 were public universities in which 1,034.2 thousand were educated ( $76.7 \%$ of all students). In this period, there were 258 non-public universities educating 314.7 thousand students $(23.3 \%$ of all students). In comparison to the previous year, the number of non-public higher education institutions dropped, and the number of students dropped by $4.7 \%$. In recent years, an increasing share of students studying at public universities has been observed, in which full time education was the dominant form $-78.7 \%$ (78.0\% in 2015/2016). The opposite situation occurs in non-public higher education institutions in which part-time studies dominate. This form of education was used by $73.9 \%$ of students of these universities $(75.7 \%$ in $2015 / 2016)$ (GUS, 2017, pp. 28-29].

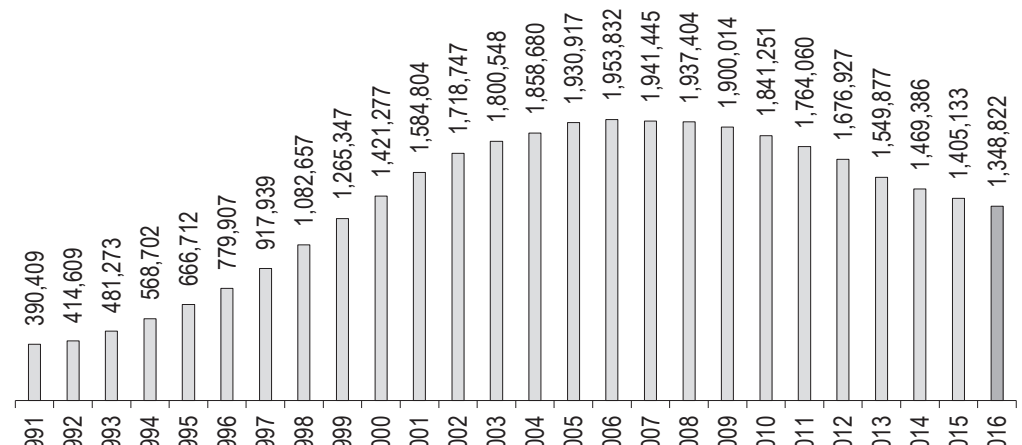

Figure 1. Number of students in Poland in the years 1991-2016

Source: GUS data, as of 31/11/2016.

In parallel with changes in the demographic environment, changes in the decision making model by potential students are observed. It was examined that the candidate's contact with the university is the last stage of decision making, and not the first contact, as was the case in the past. Secondary school students look primarily for information in the Internet. They search for faculties through search engines and visit websites of individual universities, where they will get acquainted with the offer of studies. They are, for the most part, present in social media, from where they also receive information about the possibilities of studying. They follow blogs and opinions of students from various universities, view the opinions of graduates, and watch lectures of professors from various universities on YouTube (Michalak, Mruk-Tomczak, 2018, p. 229). On this basis, they form an opinion about where to study and what faculties are valuable, whether they provide good prospects for work, and only in the final stage of decision-making, they appear inside the real walls of the university.

\section{The research methodology and results}

The aim of the study and the presented article is to identify places where young people undertaking full-time studies (as it is the dominant form of education at public universities) sought information about studying opportunities and getting to know their opinions on places where the university should be promoted. The on-line survey (CAWI) was conducted in September 2018 on a sample of 409 respondents in one of the economic faculties in the West 
Pomeranian Voivodeship (random sample, selection of a layered sample, $85 \%$ of people submitting documents for 1 year for I and II degree studies at this faculty). The analysis carried out due to the purpose of the article was limited to the answers given by candidates who submitted documents for full-time studies. The study cannot be generalized to the entire population of students in Poland due to the lack of variation in the sample (in terms of location or university profile), but the results have been obtained on a significant sample and are also valuable due to their relevance. The most important area studied was the search for information about the possibilities of studying by young people. The answers obtained are shown in Figure 2.

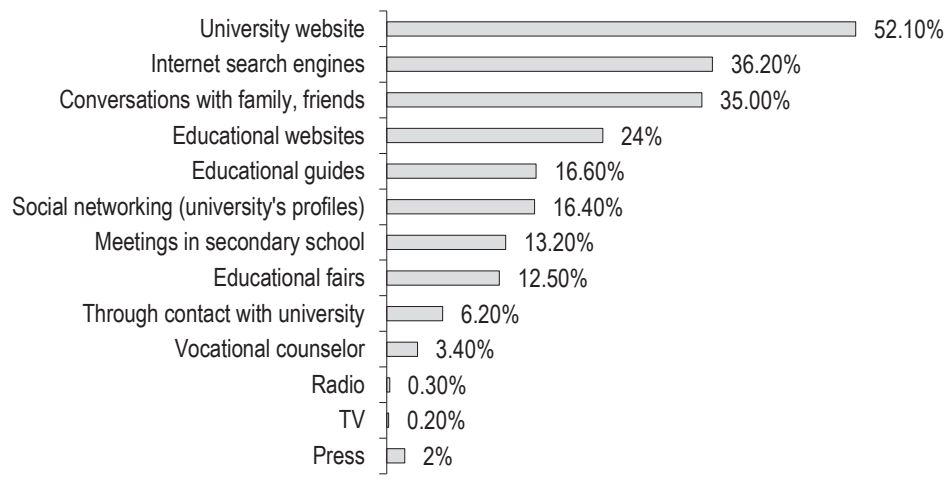

Figure 2. Places to search for information about the possibility of studying

Source: own study based on the results of the survey $n=409$.

The main place for seeking information about the study offer is the websites of individual universities, which were indicated by $52.1 \%$ of respondents. In the second place are internet search engines in which potential candidates search for information using keywords (36.2\%). In the third place, there are opinions of friends and family (35\%). The importance of traditional paper educational guides was indicated by $16.4 \%$ of respondents, but their role is taken over by educational websites, which were reviewed by $24 \%$ of respondents. It is worth noting the importance of social networking profiles (16.6\%). The next place to search for information is meetings organized in secondary schools (13.2\%) and educational fair (12.5\%). Direct contact with the university in order to obtain information was indicated only by $6.2 \%$ of respondents, which confirms the research results quoted earlier. Contact with a vocational counselor is not an accepted form of university selection (3.4\%). Traditional media such as television, radio and newspapers are used by a small percentage of respondents.

Similar results were obtained by Antczak, Kłosiewicz examining student preferences in 2016: the Internet is a basic tool for obtaining information on the educational offer of higher education institutions ( $38 \%$ of indications). Secondly, knowledge on this subject comes from friends and family (27.2\%). On the other hand, respondents mentioned about brochures much less frequently (15.2\%) (Antczak, Kłosiewicz, 2017, p. 260).The research results confirm that current students and graduates are a very important source of knowledge about the offer of a high school. The success of a university is determined by its ability to meet the needs and requirements of students. Opinion based on one's own experience, not advertising messages is more reliable. Satisfied students giving good 
testimony to the school in their environments, bring new clients (Pabian, 2002, p. 144; Antczak, Kłosiewicz, 2017, p. 267).Other studies indicate even greater importance of social media in communication with potential students. Half of the students surveyed considered the desirability of using Facebook as the most appropriate medium for presenting the university's offer on the Internet (44\%) (Antczak, Kłosiewicz, 2017, p. 259). Also K. Dembczyński draws attention to the importance of the social networking site Facebook in communication with entities in the university's environment, especially with students and graduates of the school. He points out, however, that these messages should be of engaging, not only informative character (Dembczyński, 2017, p. 73).

In addition to building relationships in the virtual world, one cannot forget about the importance of direct contacts. Open lecture cycles, academic classes or meetings with students in secondary schools remain an important and effective way to communicate with university candidates. Own, individual experiences are specific catalysts in the decision-making process (Michalak, Mruk-Tomczyk, 2018, p. 230). Nowadays, the competence potential of employees is one of the key elements of gaining an advantage over competition (Domańska, Grzegorczyk, 2017, p. 25). It requires a skilful use of the social capital of the university by delegating to meetings in competent schools, but also employees able to build good interpersonal relations. Thanks to them, potential students, in direct contacts, can find out what atmosphere prevails at a given university, what faculties the university offers and what people work there. This form of communication is more reliable than advertising, better remembered and distinguishes the university due to direct contact and non-mass character.

\section{Constructing the message}

In the survey, potential students were asked about what should be emphasized in promotional messages. The question about this aspect was of the open type, thanks to which every subject could freely answer it. Answers have been grouped into six main areas (Figure 3), the order of which reflects their validity, i.e. the frequency of the response.

\begin{tabular}{|c|}
\hline $\begin{array}{c}\text { The prospect of a good job and a professional career } \\
\text { after graduation }\end{array}$ \\
\hline The presentation of opinions and profiles of graduates \\
\hline Workshops, internships, trips \\
\hline Diversity of faculties and level of education \\
\hline Comfort and modern equipment \\
\hline Atmosphere \\
\hline
\end{tabular}

Figure 3. The most important factors when choosing a course in the opinion of the young

Source: own study based on the results of the survey, $n=409$. 
For future students, the most often emphasized was the prospect of employment and career after graduation, that is, obtaining a good education enabling to take a well-paid job. The opinions of graduates were mentioned on the second place. For the respondents, it is also important that the studies do not have value only on paper, but that the graduate should have real knowledge of the subject. For this reason, studying for young people is also a period of gaining professional experience through internships and internships, as well as trips to other universities. Students are looking for study opportunities at faculties where various fields of study are implemented. For future students it is also important in what conditions they will study, i.e. comfort and modern equipment of the faculty. This factor can be included in the physical evidence in services on the basis of which potential consumers can form an opinion on the quality of services provided. Frequently appearing answers related also to the atmosphere of studying, i.e. friendly approach of lecturers or administration employees to students.

Very similar results appeared in the studies of high school students. The factors determining the choice of the field of study turned out to be the opportunity to find a better job after graduation and well-paid work, and only on the third place reputation and prestige of the university appeared (Michalak, Mruk-Tomczyk, 2018, p. 236). Generation $Z$, or the current generation of candidates for studies, in a larger scale than in the past, introduces rationalization in the decision-making processes (Ohme, 2017, p. 36). For this reason, values that are important for the recipients of communication should form the basis for formulating messages from the university (Michalak, Mruk-Tomczyk, 2018 , p. 229). This generation $Z$ is more and more interested in the image, and with a greater reserve accepts the need to read texts (Weinschenk, 2013, p. 45). That is why, in promotional messages, it is a good idea to use films or photos that drae the attention, and at the same time, they can expose the values important for potential candidates. For this purpose, one can use a message based on the profiles of graduates in a given area. For example, the possibility of constructing the message is indicated by J. Wiktor, describing it as a recommendation, by using in the advertising message the category of "personalities", both well-known people and "average" people, typical representatives of the target group (Wiktor, 2013, p. 189).

\section{Conslusions}

Changes observed in the socio-economic environment of the country and the dynamic development of modern technologies have a significant impact on the activities of universities, as well as changes in behavior and the decision-making model of candidates for studies (Michalak, Mruk-Tomczak, 2018, p. 227). According to the principles of marketing communication, the university should communicate with its environment through various communication channels and forms of promotion (especially public relations and advertising activities). This way of acting is called integrated marketing communication with the environment, thanks to which it is possible to achieve synergy (Pabian, 2002, p. 142; Wiktor, 2013, p. 82). In the age of information society, the media that young people like to use are changing and their activity is largely shifting to the Internet. This is crucial for a university that wants to reach them with information about its offer.

The author's research indicates the need for a multi-channel communication method of the university. Regarding the choice of the communication channel, one should take care of the modernity and attractiveness of the university's website as the most important place for obtaining information about fields of study. It is also worth investing in search engine advertisements (e.g. Google Ads), thanks to which information about the university and the offered trends will be in the first positions in the search engines. One should pay attention to the necessity of the presence of the university in social media and educational online portals, at the expense of presence in traditional 
media. However, the direct channel is not without significance, either during open lectures organized in high schools, at stands during educational fairs or contact with the candidate coming in the last stage of decision making at the university. Regarding the method of shaping the message, one should take care of the rational nature of the message, emphasizing the prospects of work after graduation, especially by presenting the profiles of graduates of the faculty and the possibility of using practical workshops or internships during education. Adaptation of the communication channel and the way of constructing a promotional message to solutions applied by potential candidates for studies will enable the university to provide young people with the information in the right place and form.

\section{References}

Antczak, B., Kłosowicz, L. (2017). Działania promocyjne, komunikacja wewnętrzna i opinie studentów dotyczące funkcjonowania WSGE. Raport z badań. Journal of Modern Science, 3 (34), 249-267.

Alwahaishi, S., Snášel, V. (2013). Consumers' Acceptance and Use of Information and Communications Technology: A UTAUT and Flow Based Theoretical Model. Journal of Technology Management \& Innovation, 8 (2), 61-73.

Dembczyński, K. (2017). Analiza różnic zaangażowania społeczności w serwisie Facebook, z uwzględnieniem udziału marketingu treści, wybranych uczelni wyższych w Polsce i za granicą. Zeszyty Naukowe Zachodniopomorskiej Szkoły Biznesu. Firma i Rynek, 1 (51), 65-74.

Do 2023 roku zostanie w Polsce do 100 uczelni prywatnych (2013). Retrieved from: https://www.forbes.pl/kariera/do-2023-rokuzostanie-w-polsce-100-uczelni-prywatnych/9917kvm data.

Gamper, H. (2012). How Can Internet Comparison Sites Work Optimally for Consumers. Journal of Consumer Policy, 35 (3), $333-353$.

Grzywińska-Rąpca, M., Elżbieta Lorek, E., Markowski, L. (2018). Społeczne aspekty zróżnicowania rozwoju społeczeństwa informacyjnego. Roczniki Kolegium Analiz Ekonomicznych/Szkoła Główna Handlowa, 49, 23-35.

Heath, R. (2013). Uwieść podświadomość. Gdańsk: GWP.

GUS (2017). Szkoły wyższe i ich finanse w 2016 roku. Warszawa.

Michalak, S., Mruk-Tomczak, D. (2018). Komunikacja oferty edukacyjnej uczelni wyższej w świetle potrzeb kandydatów na studia. Handel Wewnętrzny, 4 (375), 227-240.

Ohme, R. (2017). Emo sapiens. Harmonia emocji i rozumu. Wrocław: Wydawnictwo Bukowy Las.

Pabian, A. (2002). Promocja szkoły wyższej. Nauka i Szkolnictwo Wyższe, 2 (20), 138-144.

Weinschenk, S. (2013). 100 rzeczy, które każdy projektant powinien wiedzieć o potencjalnych klientach. Gliwice: Helion.

Wiktor, J.W. (2013). Komunikacja marketingowa. Warszawa: Wydawnictwo Naukowe PWN.

Cite this article aS: Ostrowska, I. (2018). Construction of promotional message of a higher school in the context of changes in behaviors of potential students. European Journal of Service Management, 4 (28/2), 311-317. DOI: 10.18276/ejsm.2018.28/2-37. 